\title{
International Population Congress in Paris
}

A

VERY successful Congress to discuss population problems was held in Paris on July 29August 1 last, under the presidency of M. Adolphe Landry. The Congress was honoured by the patronage of M. Albert Lebrun, President of the Republic, who attended the opening session. Before this, on July 28, a meeting of the General Assembly of the International Population Union took place; and it may be noted that the Congress was held under the auspices of the Union, which took a definite part in the arrangements for the Congress. At the General Assembly, M. Adolphe Landry was elected president of the Union in succession to Sir Charles Close. M. Landry is a former Minister of State, whose interest in demographic matters is well known. $\mathrm{He}$ has written several works on the subject, particularly "La Révolution Démographique" (1934). His management of the Congress was most happy.

During the four working days of the Congress, about 170 papers were presented for reading and discussion. Abstracts of the papers were available at the opening of the Congress, but, as always happens at international meetings of this kind, individual delegates must select their lectures and must necessarily miss some contributions of importance. Some of the papers, particularly the mathematical ones, were difficult to follow at the time, but will be available for study when the proceedings are published. Perhaps the real value of these congresses consists largely in the personal contacts established between workers of different nationalities, who cease to be abstractions to each other and can use the occasion for informal discussions and exchange of views.

The Congress was divided into five sections which were simple and sufficiently comprehensive to cover the whole field. A few of the titles of the lectures will serve to give an idea of the kind of questions which were discussed, thus: "The Calculation of Death-Rates"; "Sur les possibilités de retour à l'équilibre pour une population régressive ou rétro. grade"; "A Population Growth-Curve for England and Wales" ; "Essai d'établissement d'un indice de densité économique de population" ; "Considérations sur la politique démographique d'Auguste et ses effets" ; "The Length of Life in the Early Roman Empire"; "Recent Population Movements in the Irish Free State"; "Les types de migrations"; "Die natürliche Bevölkerungsvermehrung Wiens"; "L'évolution sociale de la population italienne à travers les recensements" ; "Growth of Urban Population in the United States"; "Fécondité et classe sociale en Suède"; "L'influence du chomage sur la famille" ; "Die neue deutsche Bevölkerungsentwicklung" ; "Rural Population and Government Policies in the United States"; "Biotypes et fécondité"; "Constitution physique de la jeunesse polonaise".

Now, this is a very mixed bag; but the various aspects of the subject are inter-linked and affect one another. It would be a mistake, for example, to discuss only the statistical side of the population question and to omit consideration of quality. In the same way, an adequate examination of presentday tendencies necessarily involves a study of what has happened in the past ; and a discussion of demographic facts in one country is imperfect without reference to what is happening elsewhere.
In view of the considerable range of matter discussed and of the impossibility of being present at more than one section at a time, one can only get a limited, personal impression of the meeting, an impression to be corrected by a study of the proceedings when these are eventually published. Meanwhile, no one can have attended this Congress without having learnt something more about the intricacies of the subject than he knew on arrival. Such papers as that of Prof. Burgdörfer, for example, which dealt chiefly with the effect on the birth-rate of Germany of the new population policy in that country, have an importance for all of us. The abstract of his paper ends with the following sentence: "L'exemple de l'Allemagne prouve que, dans notre civilisation occidentale, il est possible de lutter avec succès contre la baisse du taux de natalité".

Amongst numerous other important contributions to the proceedings may be mentioned the paper by Prof. A. M. Carr-Saunders and Mr. R. S. Walshaw, on "Recent Population Movements in Ireland". The authors remark that, "There is less emigration [from Ireland] than formerly, and it is going to the United Kingdom instead of to the United States. This raises important problems for the United Kingdom, which is faced with the prospect of a declining population. The United Kingdom is still pursuing a policy of giving financial assistance to emigrants going to the Dominions. It is doubtful if this can be continued, and it is a question whether the United Kingdom will not be peopled from Ireland".

\section{RACE AND RaCial Doctrine}

ONE section of the International Congress was devoted to matters coming under such heads as biometry, biotypology and heredity. Opportunity was thus afforded for the discussion of a variety of problems connected with the racial question, of which advantage was taken by the Management Committee of the Groupement d'Etude et d'Information "Races et Racisme", an organization which has undertaken the dissemination among the French people of in formation relating to the fallacies and consequences of the racial doctrines now current in Germany, and is responsible for the publication of the periodical Races et Racisme (see p. 458). Arrangements were made for presentation to the Congress of a number of communications dealing with questions bearing upon "race" and their formal discussion. The following account is based upon a report furnished by the organization.

Among those present were the veteran Prof. Franz Boas, who notwithstanding his advanced years had crossed the Atlantic from America for the special purpose of taking part, and Prof. Lips and Prof. Fairchild, also from the United States. A certain 'liveliness' developed in the proceedings owing to the presence of numerous representatives of Germany, among whom were Prof. Rüdin, director of the Kaiser Wilhelm Institute, Prof. Verschuer of the University of Frankfort, and Prof. Hellpach of Heidelberg.

In opposition to views put forward by German delegates on 'purity' of race and 'nordization', Prof. Boas, basing his remarks on the experience of half 